\title{
ISOLATION AND ANALYSIS OF STEROIDAL SAPONINS FROM POLYGONATUM ODORATUM (MILL.) DRUCE
}

\author{
Cristina MOGOȘAN ${ }^{1}$, Ilioara ONIGA', Mircea TAMASȘ \\ ${ }^{1}$ Iuliu Hațieganu University of Medicine and Pharmacy, Department of Pharmacology, Physiology, \\ Physyiopathology, Faculty of Pharmacy, 4 Louis Pasteur str., RO-400349 Cluj-Napoca, Romania \\ ${ }^{2}$ Iuliu Hațieganu University of Medicine and Pharmacy, Department of Pharmacognosy, Faculty of Pharmacy, \\ RO-400349 Cluj-Napoca, Romania \\ ${ }^{3}$ Iuliu Hațieganu University of Medicine and Pharmacy, Department of Botany, Faculty of Pharmacy, \\ RO-400349 Cluj-Napoca, Romania \\ e-mail: mtbotanica@yahoo.com
}

\begin{abstract}
We isolated the steroidal saponins from the rhizomes of Polygonatum odoratum (Mill.) Druce with an efficiency of $4.50 \%$ which represents 7 fractions identified by thin-layer chromatography (TLC), of which 3 were furostanics and 4 spirostanics. After the acid hydrolysis of the saponins, one aglycone (sapogenine) was identified by TLC. Further, we have determined the physico-chemical and the biological properties of the isolated saponins.
\end{abstract}

Key words: Polygonatum odoratum, steroidal saponins, sapogenine.

\section{Introduction}

Polygonatum odoratum (Mill.) Druce, in the Asparagaceae family, popularly known as "Solomon's seal" or "cock's tail" (Fig.1), is a leafy species of wild indigenous perennial, with a horizontal rhizome, which can be found from steppic areas up into the beech tree zone, on forest edges and in scrub. It is one of the four species of Polygonatum in the Romanian flora [3, 14].

In popular medicine this plant is known for the rhizomes which are used for their antiinflammatory properties and for treating rheumatic diseases [7]. The rhizomes have not been analyzed before in Romania for their chemical compounds, nor for their pharmacological action. In the literature, the presence of steroidal saponins is identified alongside mucilage, tannin and traces of alkaloids, cardiotonic glycosides, and calcium oxalate [7,19]. Constantinescu and Sommer have performed phytochemical and pharmacodynamical researches on the aerial parts of this plant and showed that they contain phytosterols, fatty acids and reducing factors, along with steroidal aglycones [5]. The only references to steroidal saponins from the rhizomes of this species are those of Janeczko et al., cited by Hosttetman et Marston, 1995 [8], who isolated and characterized a new saponin, named polyfuroside, in addition to the three previously known, as confirmed by Lin et al. (1994) [9]. 


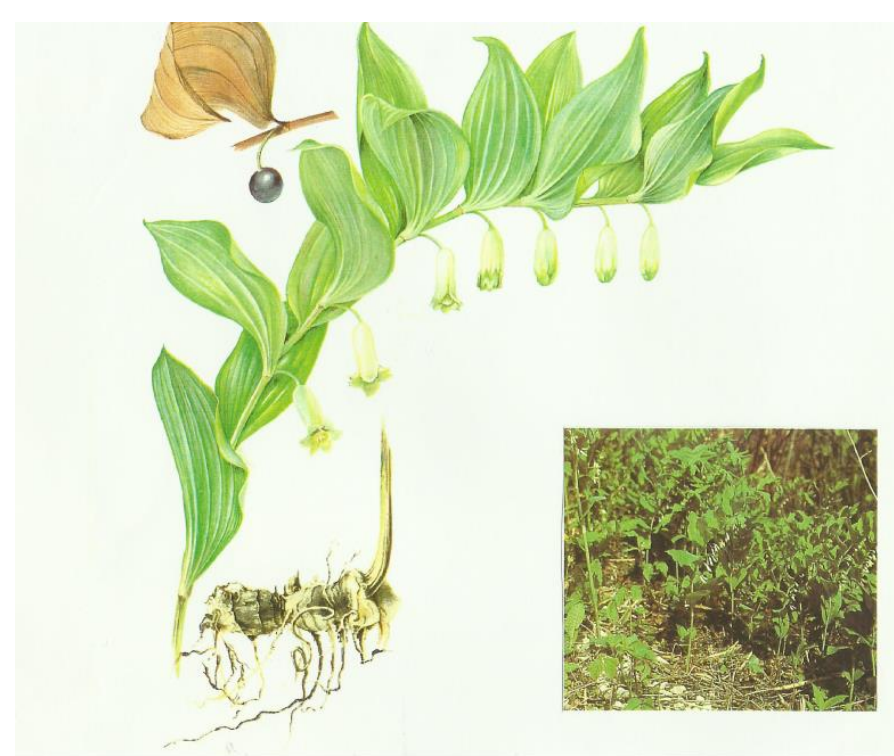

Fig. 1: Polygonatum odoratum (Mill.) Druce, Asparagaceae family.

We tested the anti-inflammatory, analgesic and antipyretic actions, but also the digestive action of tincture and steroidal saponins from the rhizomes of the plant on rats, the saponins having an important anti-inflammatory effect, without significant digestive side effects $[10,11,12]$.

Taking into consideration that up until now the steroidal saponins from the Romanian product have not been isolated and analyzed, our goal was to isolate and analyze these saponins from rhizomes of Polygonatum odoratum, harvested from Romania. Analyses on the steroidal saponins have been made so far from the rhizomes of Tamus communis [12], from Dioscorea caucasica acclimatized in Romania [16], from the seeds of Trigonella foenum-graecum [15] and from Ruscus aculeatus [1].

The aglycones of steroidal saponins and especially diosgenin are used as precursors during the semisynthesis of some steroidal compounds with medical significance, such as steroid hormones [2].

\section{Materials and Methods}

The rhizomes of Polygonatum odoratum were harvested from Făget forest close to ClujNapoca city during their flowering period which occurs in May-June. A voucher specimen was deposited at the Herbarium of the Department of Pharmaceutical Botany at "Iuliu Haţieganu" University of Medicine and Pharmacy, Cluj-Napoca. Rhizomes were detached from the aerial parts, washed from the remains of the soil, sectioned into $3-5 \mathrm{~cm}$ fragments and dried at room temperature on a paper sieve. After drying, the rhizomes were ground to a fine powder (sieve VI, FR X). This powder was used to preparing a tincture $1: 10$, with $70^{\circ}$ ethanol, using the technique indicated by FR X [18]. We had also prepared a 5\% methanol extract by refluxing with methanol over hot boiling water for 30 minutes.

For the isolation of steroidal saponins, $100 \mathrm{~g}$ of rhizome powder was used, which was introduced into a cartridge of filter paper that was skimmed with ethyl ether into a Soxhlet device. After the removal of the solvent, the skimmed powder was extracted twice with $1000 \mathrm{ml}$ and 500 $\mathrm{ml}$ methanol, respectively, at reflux, on the boiling water bath into a $2000 \mathrm{ml}$ round-bottomed balloon, which had an ascendant refrigerant, for 60 and 30 minutes, respectively. The methanolic 
solutions that were decanted were reunited, filtered and then concentrated under low pressure at a temperature below $50^{\circ} \mathrm{C}$, into a Rotary evaporator, up to the volume of $50 \mathrm{ml}$. The concentrated methanolic solution was poured, thin thread into a Berzelius glass which contained $500 \mathrm{ml}$ ethylic ether, shaking with a wand, until the steroidal saponins precipitated. Precipitated saponins were filtered with a Buchner funnel, washed with $100 \mathrm{ml}$ ethylic ether, and then introduced together with the funnel into a dryer with vacuum valve, on calcium chloride. Further, these were added to the vacuum and left to rest for 3 days in order to dry. They were weighed, relative to the vegetal material and kept in bottles securely closed in the dryer on $\mathrm{CaCl}_{2}$.

For the isolated saponins the foaming index was determined and the hemolytic action (after FR X) and identification reactions were carried out (with concentrated $\mathrm{H}_{2} \mathrm{SO}_{4}$, with LibermanBurchard reagent). For the tincture 1:10, the residue by evaporation, refraction index and density $[2,4,18]$ were determined.

Qualitative analysis of the isolated steroidal saponins and of those contained in the tincture was carried out by thin-layer chromatography (TLC), under the following experimental conditions:

- Stationary phase: Silica gel $\mathrm{G}_{60} \mathrm{~F}_{254}$ of $0.25 \mathrm{~mm}$

- Mobile phase: Chloroform-methanol-water (65:35:10 v/v) [6]

- Distance of migration: $10 \mathrm{~cm}$

- Quantity applied: $20 \mu 1$, in linear spots of $10 / 3 \mathrm{~mm}$

- Identification reagents: R. Ehrlich (for furostanic saponins) and R. Methanol - Sulphuric acid (1:1), for all steroidal saponins [17]

- Samples to analyse: steroidal saponins isolated from P. odoratum 1\% into methanol: water $(1: 1)$

- Tincture 1:10 from the rhizomes of P. odoratum

- Methanolic extract 5\% from the rhizomes of P. odoratum, obtained at heat

- Steroidal saponins isolated from Dioscorea caucasica $1 \%$ into methanol: water (1:1)

- Steroidal saponins isolated from Ruscus aculeatus $1 \%$ into methanol: water (1:1).

For obtaining the aglycones (saponigens) of these saponosides, we have carried out acid hydrolysis of the isolated saponines, using the technique indicated by Drapeau et al. [6]. Qualitative analysis of aglycones resulted from the hydrolysis was performed by using TLC in the following experimental conditions:

- Stationary phase: Silica gel $\mathrm{G}_{60} \mathrm{~F}_{254}$ of $0.25 \mathrm{~mm}$

- Mobile phase: Hexane-ethyl acetate (85:15 v/v)

- Standard solution: diosgenin $0.1 \%$ in chloroform, $\beta$-sitosterol $0.1 \%$ in chloroform

- Quantity applied: $20 \mu 1$ of the sample and standard solution

- Distance of migration: $10 \mathrm{~cm}$

- Identification reactive: phosphoric acid $85 \%$ with $0.3 \%$ formic aldehyde and heating the chromatographic plate in the oven at $110^{\circ} \mathrm{C}$ for 5 minutes.

\section{Results and Discussions}

The tincture (1:10) obtained from the rhizomes of Polygonatum odoratum is a clear liquid, light yellow-brown in color, with a residue by evaporation of $6.88 \%$, refraction index (n) of 1.370 , and density $\mathrm{p} 24 \mathrm{oC}$ of 0.90687 . 
Steroidal saponins were isolated from the rhizomes with an efficiency of $4.50 \%$ relative to the dried vegetal product. They are represented by a white-yellow powder, hygroscopic, soluble in water and diluted alcohol; and insoluble in concentrated alcohol and non-polar organic solvents. They have a foaming index of 250 and turned positive in reactions with the two reagents, also not presenting hemolytic properties.

From the TLC analysis of saponosides (Fig. 2) we have found that by using R. Ehrlich on chromatogram three characteristic red stains appeared for furostanic saponosides (with Rf 0.075; 0.115 and 0.150 ) and after the use of methanol-sulphuric acid reagent, 7 brown stains appeared, due to the presence of furostanic and also spirostanic saponins. These findings mean that, by using the difference in stains given by the two reagents, there are 4 spirostanic saponins and 3 furostanic saponins, with a total of 7 steroidal saponins, which is three more than already known.

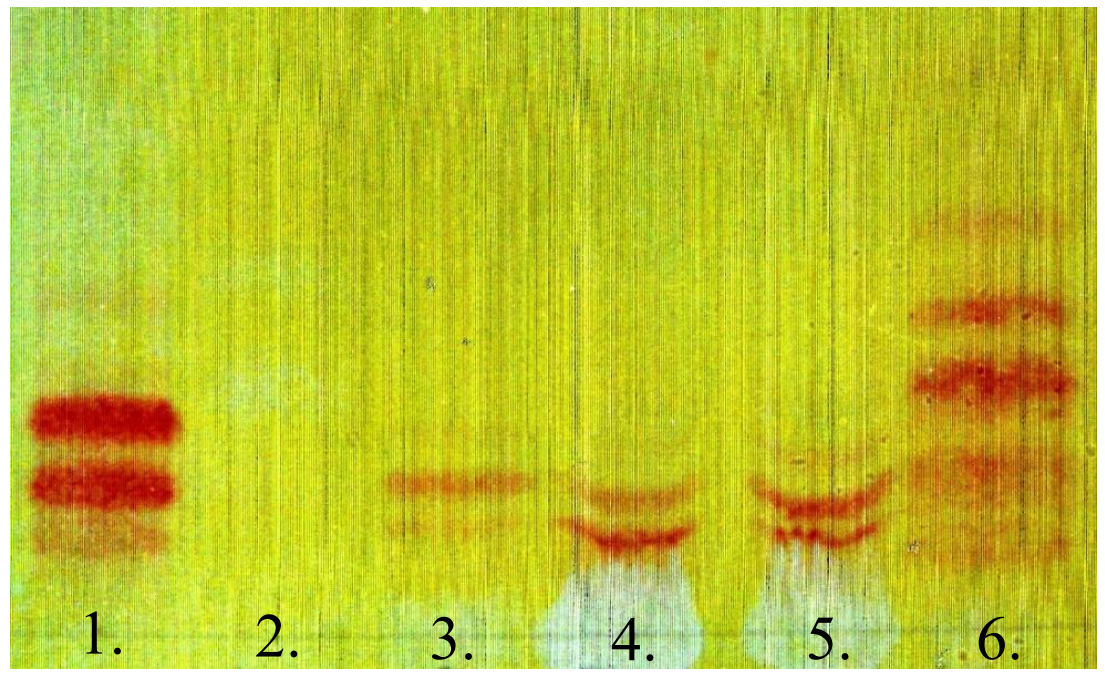

Fig. 2: The TLC from P. odoratum saponins (1. Dioscorea caucasica saponins; 2. Digitonin; 3. P. odoratum saponins; 4. P. odoratum tincture; 5. P. odoratum extract; 6- Ruscus aculeatus saponins).

The analysis of the chromatogram for steroidal aglycones (Fig. 3) showed that saponosides from the rhizomes of $P$. odoratum have a single aglycon, identified at $\mathrm{Rf} 0.27$, different from diosgenin, also coloured brown, but which can be identified at Rf 0.15 and the one of $\beta$-sitosterol at $\mathrm{Rf} 0.23$. This assumes that the aglycon presents 7 different ways of glycosidation in the plant, which corresponds to the 7 saponosides identified by the chromatogram.

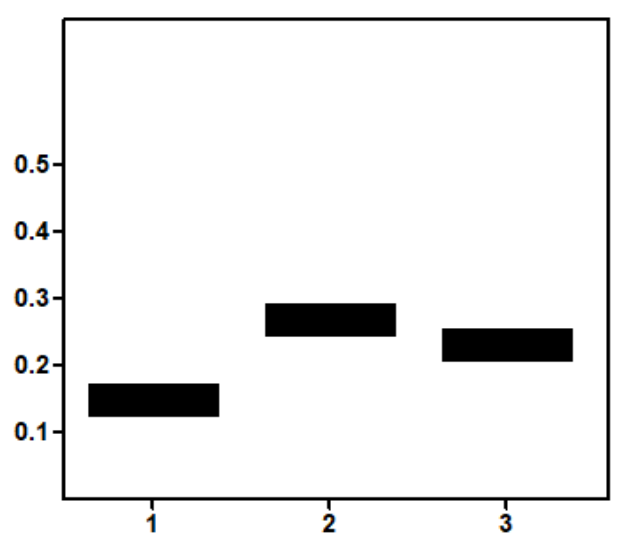

Fig. 3: Aglycon chromatogram (1-diosgenin, brown, $\mathrm{Rf}=0.15 ; 2$-steroidal aglycon dark brown, $\mathrm{Rf}=0.27$; 3 - $\beta$-sitosterol, brown, $\mathrm{Rf}=0.23$ ). 
Analyzing the absorption spectrum of this aglycon shows that it has a maximum of absorption at $280 \mathrm{~nm}$ (Fig 4).

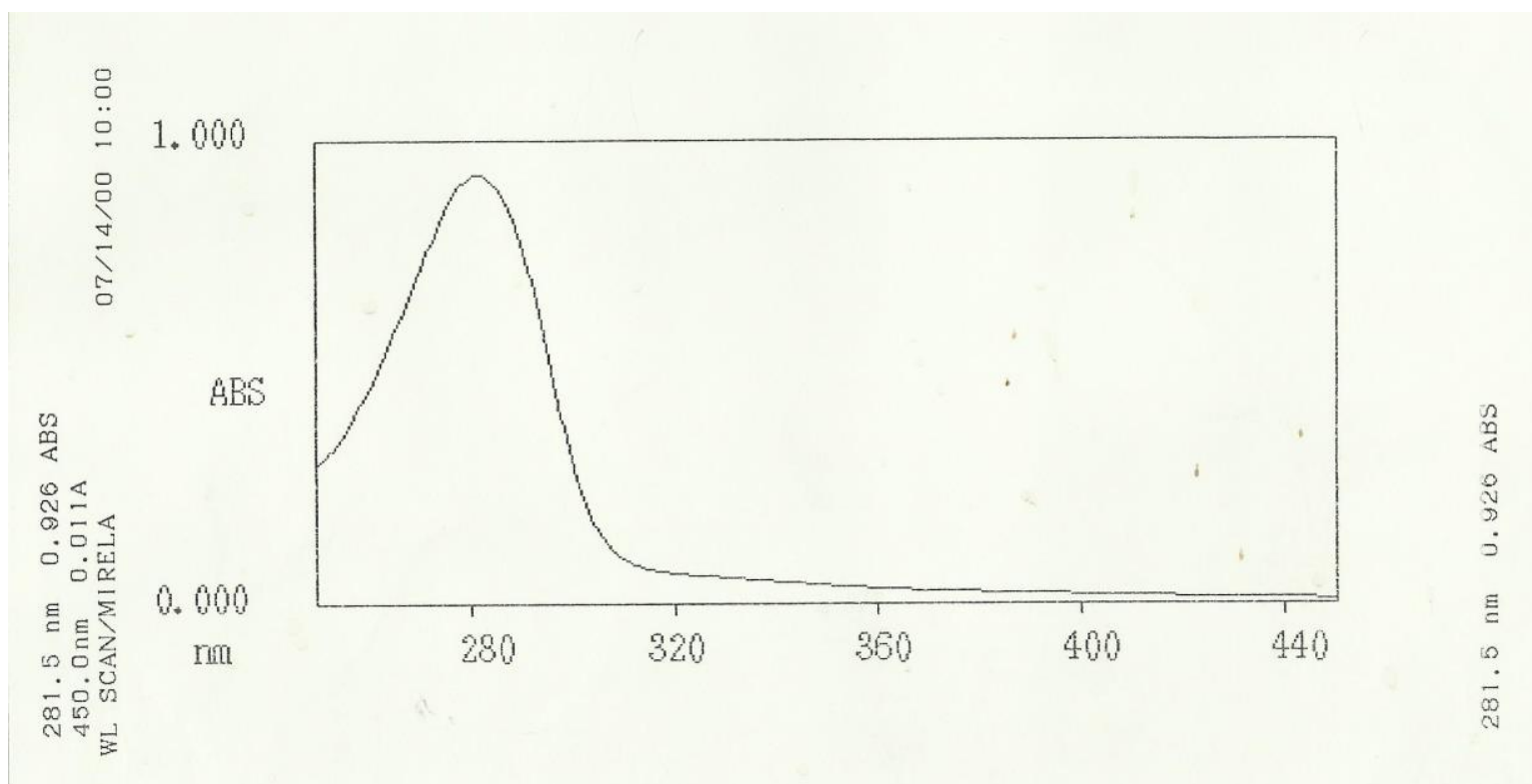

Fig. 4: UV spectrum for the aglycon of steroidal saponin from Polygonatum odoratum.

\section{Conclusions}

- From the rhizomes of Polygonatum odoratum, harvested in Romania we had isolated steroidal saponins with an efficiency of $4.50 \%$.

- Identification of steroids saponins was pointed out by the positive reactions using specific reagents.

- We obtained and characterized from physico-chemical point of view the tincture 1:10 from the dried rhizome powder.

- By TLC analysis for saponosides we have highlighted on the chromatogram 7 steroidal saponozides, of which 3 were furostanics and 4 were spirostanics.

- TLC analysis for aglycons that resulted from the hydrolysis of saponosides shows that rhizomes of $P$. odoratum contain only a single steroid aglycon, which has different glycosidation ways, different from the diosgenin, used as the standard substance and has a characteristic UV absorption at $280 \mathrm{~nm}$.

\section{REFERENCES}

1. Balica, G., Tămaș, M., Deliu, C., Crișan, G., 2006, Biotechnological and Phytochemical Research on Ruscus aculeatus L., Proceedings of the 4th Conf. AMAPSEEC, Iași: 347-353.

2. Bruneton, J., 1993, Pharmacognosie, Phytochimie, Plantes Medicinales, Tec.Doc. Londres, Paris, NewYork: 545-547.

3. Ciocârlan, V., 2009, Flora ilustrată a României, Edit. Ceres, București: 912-914.

4. Ciulei, I., Istudor, V., Palade, M., Niculete, E., Gârd, C., 1995, Analiza farmacognosică și fitochimică a produselor vegetale, Ed. Medicală, București.

5. Constantinescu, E., Sommer, L, 1968, Chemische-Pharmacodynamische Vorunterschung Einiger arten von Polygonatum, Herba Hungarica, 7 (1): 59-65. 
6. Drapeau, D., Sauvaire, Y., Blanch, H.W., Wilke, C.R., 1986, Improvement of Diosgenin Yield from Dioscorea deltoidea Plants cells Culture by use of a NonTraditional Hydrolysis Method, Planta Medica, 6: 433-458.

7. Grigorescu, E., Lazăr, M.I., Stănescu, U., Ciulei, I., 2001, Index fitoterapeutic, Ed. Cantes, Iași: 912-914.

8. Hostettmann, K., Marston, A., 1995, Saponins, Cambridge Univ. Press.

9. Lin, H.W., Han, G.Y., Liao, S.X., 1994, Active constituents of the Chinese Traditional Medicine, Polygonatum odoratum, Хао Хие Хиеbao, 29 (3): 215-222.

10. Mogoșan, C., 2001, Cercetări farmacologice experimentale privind unele produse vegetale cu proprietăți antiinflamatoare, Teză de doctorat UMF Carol Davila București.

11. Mogoșan, C., Oniga, I., Pârvu, A., Tămaş, M., Dobrescu, D., 2000, Acțiunea tincturii și a saponinelor steroidice din rizomii de Polygonum odoratum asupra tubului digestiv, Farmacia, 48 (1): 39-44.

12. Mogoșan, C., Pârvu, A., Voștinaru, O., Tămaş, M., 2000, Studiul efectului antiinflamator al Tincturii și saponinelor steroidice obținute din rizomii de Polygonatum odoratum în două modele experimentale de inflamație acută, Farmacia, 48 (2): 55-61.

13. Radu, A., Tămaș, M., Zidaru, D., Contribuții la studiul farmacobotanic al plantei Tamus communis, Farmacia, 19 (5): 311-320.

14. Sârbu, I., Ștefan, N., Oprea, A., 2013, Plante vasculare din România, Edit. Victor B. Victor, București.

15. Szocs, D., 2003, Studiul fitochimic şi farmacologic al speciei Trigonella foenum graecum L. (Fabaceae), Teză de doctorat, UMF Tg. Mureș.

16. Tămaș, M., Roșca, M., Deliu, C., 1989, Identificarea diosgeninei în culturi de țesut in vitro de Dioscorea caucasica Lipsky, Clujul Medical, 62 (2): 184-187.

17. xxx, 1974, Dyeing Reagents for TLC , E. Merck, Darmstadt.

18. xxx, 1993, Farmacopea Română, ediția a X-a, Edit. Medicală, București.

19. Xxx, Flora Republicii Socialiste România, Ed. Acad. RSR, București, vol.XI: 386-389.

\section{IZOLAREA ȘI ANALIZA SAPONINELOR STEROIDICE DIN POLYGONATUM ODORATUM (MILL.) DRUCE}

\section{(Rezumat)}

Din rizomii de Polygonatum odoratum (Mill.) Druce au fost izolate saponinele steroidice cu un randament de 4,50\%, care sunt reprezentate de 7 fracțiuni, evidențiate prin CSS, dintre care 3 furostanice și 4 spirostanice. În urma hidrolizei acide a saponozidelor s-a pus în evidență, prin CSS, un singur aglicon (sapogenină). Au fost determinate proprietățile fizico-chimice și biologice ale saponinelor izolate. 